School of Finance

University of St.Gallen

\title{
The Determinants of Microinsurance Demand
}

MARTIN ELING

ShaileE PRADHAN

JOAN T. SCHMIT

WORKING PAPERS ON FINANCE No. 2013/8

INSTITUT FÜR VERSICHERUNGSWIRTSCHAFT (I.VW - HSG)

JUNE 2013 


\title{
The Determinants of Microinsurance Demand
}

\author{
Martin Eling, Shailee Pradhan, Joan T. Schmit ${ }^{1}$
}

\begin{abstract}
The purpose of this article is to structure the extant knowledge on the determinants of microinsurance demand and to discuss unresolved questions that deserve future research. To achieve this outcome, we review the academic literature on microinsurance demand published between 2000 and early 2013. The review identifies 12 key factors affecting microinsurance demand: price, wealth, risk aversion, non-performance risk, trust and peer effects, religion, financial literacy, informal risk sharing, quality of service, risk exposure, age, and gender. We discuss the evidence of how each of these 12 factors influences demand, both within the microinsurance and the traditional insurance markets. A comparison with traditional markets shows an unexpected (negative) effect of risk aversion on microinsurance demand, with trust perhaps being the intervening factor. Other relevant results include the importance of liquidity (and/or access to credit), informal risk sharing, and peer effects on the decision to buy microinsurance. The influence of trust on insurance take-up and the unanticipated results for risk aversion are fertile areas for future research.
\end{abstract}

Keywords: Microinsurance; insurance; demand; enrolment; participation; take-up

\footnotetext{
${ }^{1}$ Martin Eling (martin.eling@unisg.ch) and Shailee Pradhan (shailee.pradhan@unisg.ch) are both with the Institute of Insurance Economics at the University of St. Gallen, Kirchlistrasse 2, 9010 St. Gallen, Switzerland. Joan T. Schmit (jschmit@bus.wisc.edu) is with the Department of Actuarial Science, Risk Management \& Insurance at the School of Business of the University of Wisconsin-Madison, 5194 Grainger Hall, 975 University Avenue, Madison, WI, 53706, U.S.
} 


\section{Introduction}

Life is risky for the poor in developing countries. Illnesses, natural disasters, unemployment, and accidents affect this segment of the population more severely than others due to their lack of formal insurance and their limited social safety nets. Many rely on informal transfers from friends, families, and relatives; however, such transfers often are deficient compared to what is needed. ${ }^{2}$ Microinsurance has come to be seen as an important means of managing risk for the poor, but yet demand for it is relatively low. ${ }^{3}$

Until relatively recently, the literature on microinsurance demand was limited to a variety of field studies written by practitioners; only a few works were of a traditional academic nature, that is, based on sufficiently large and unbiased samples and employing rigorous statistical analyses. Since the early 2000s, however, the field has blossomed to the point where a detailed and structured accounting of what we know and, perhaps more importantly, what we do not know is needed to guide policy decisions as well as direct future research efforts.

The intent and contribution of this paper is to organize the extant knowledge on the determinants of microinsurance demand. We undertake a rigorous review of 41 papers that specifically discuss this topic. We identify 12 aspects that have received significant attention in the academic literature. Using Outreville's ${ }^{4}$ insurance demand framework, we categorize these 12 characteristics into several important factors: economic factors (price, wealth), social and cultural factors (risk aversion, non-performance risk, trust and peer effects, religion, financial literacy), structural factors (informal risk sharing, quality of service, risk exposure), and personal and demographic factors (age, gender).

\footnotetext{
${ }^{2}$ See Fafchamps and Lund (2003).

${ }^{3}$ See Cole et al. (2013); Giné et al. (2008); Jowett (2003); Thornton et al. (2010).

${ }^{4}$ See Outreville (2013).
} 
A second contribution of this paper is its comparison of microinsurance markets with traditional insurance markets. Traditional insurance refers to insurance geared toward moderate to high income markets predominantly in developed countries that have an established insurance culture. ${ }^{5}$ Several findings emerged from this comparison. First, while the influence of risk aversion in traditional markets is ambiguous, it is almost universally negative in the microinsurance domain. Various studies point to the importance of trust in insurance provider as a major factor in this surprising result, a factor that perhaps explains the ambiguous results in the traditional market. Second, while price is negatively related to takeup in both markets, as expected, the literature suggests that price alone cannot account for the low take-up rates in the microinsurance market. Similarly, while wealth/income are positively related to take-up in both markets, lack of resources (referred to as credit or liquidity constraints) does not fully explain why the microinsurance market is not more robust. Also somewhat surprising is that informal risk-sharing mechanisms can have either a positive ${ }^{6}$ or a negative $^{7}$ effect on demand for microinsurance. Further study of all these characteristics is likely to improve both the traditional and the microinsurance markets.

This article is organized as follows. In the following section, we first present results from empirical analyses of the determinants of microinsurance demand, focusing on 12 key factors highlighted in the literature. In Section 3 we compare microinsurance and traditional insurance markets and derive future research needs. Conclusions are presented in Section 4.

\footnotetext{
${ }^{5}$ For a more comprehensive distinction between microinsurance and traditional insurance, see Lloyd's (2009).

${ }^{6}$ See Mobarak and Rosenzweig (2012).

${ }^{7}$ See Jowett (2003).
} 


\section{Determinants of (micro) insurance demand}

As Outreville ${ }^{8}$ notes in his review of the literature on the relationship between insurance and economic development, insurance demand models typically focus on life insurance, yet 'could be generalized to the consumption of all insurance products as part of a basket of securities available to the consumer'. The general model reveals the following relevant influences: insurance price, policyholder wealth and/or income, policy payout (or, perhaps, perceived payout, including the concept of credibility ${ }^{9}$ ), discount rates to address the time dimension between decision and result, and utility function. Outreville ${ }^{10}$ further provides a framework to summarize results from the empirical literature. That framework presents results according to economic factors (generally, the price and wealth/income influences), social and cultural factors (which focus on utility functions), structural factors (underlying market conditions, including discount rates), and personal and demographic factors (representations of loss exposures).

These same factors should be relevant in the microinsurance market, and yet it is expected that their actual influence, including strength and impact, will vary between the two types of markets. The reasons are substantial variations in income/wealth level, quality of legal and regulatory environment, education, financial literacy, availability of informal risksharing networks, quality of service, and exposure to risks. ${ }^{11}$ As we discuss the empirical evidence associated with each key factor, we also will present evidence of similarities and differences between the two markets. Such information ought to help focus future research.

\footnotetext{
${ }^{8}$ See Outreville (2013, p. 80).

${ }^{9}$ For an example of possible contract non-performance, see Doherty and Schlesinger (1990).

${ }^{10}$ See Outreville (2013).

${ }^{11}$ It is our belief that the underlying theory is not different for microinsurance; rather, the factors across the two markets differ. We thus can use the same model, just with distinct representations of the factors.
} 
Over the past 10 to 15 years, there has been a tremendous expansion of academic research on microinsurance markets. ${ }^{12}$ Indeed, we are now at the point where some of what we are learning in the microinsurance domain, such as the relevance of trust in generating demand, may shed some light on the traditional insurance market as well. Yet numerous unanswered questions remain, especially given the persistently low take-up rate of microinsurance around the globe, even when coverage is subsidized.

With the goal of advancing the field, we review studies on microinsurance demand covering the period from 2000 to early 2013. Our search and identification strategy followed Biener and Eling ${ }^{13}$ with the purpose of ensuring that the studies included meet academic standards (the search strategy description is available upon request). This strategy resulted in the identification of 41 papers that specifically analyse demand issues in microinsurance markets.

Based on Outreville's ${ }^{14}$ categorization scheme, we identified 12 factors considered key determinants of microinsurance demand, which are listed in Table 1. Some variables, such as trust and peer effects, financial literacy, informal risk sharing, and quality of service, have not been considered explicitly in traditional markets, and some variables may be categorized differently. $^{15}$

\footnotetext{
${ }^{12}$ See Biener and Eling (2012).

${ }^{13}$ See Biener and Eling (2012).

${ }^{14}$ See Outreville (2013). We note, however, that Outreville's focus is on cross-national evaluations, which are more focussed on macro factors than on micro factors. Zietz (2003), in contrast, considers the literature on life insurance demand within specific markets, focussing on micro factors. We combine the efforts of both authors in constructing our categorization of the literature.

${ }^{15}$ For instance, Zietz (2003) considers age and religion under personal and demographic factors. Our categories are intended to be as consistent as possible with those of Outreville (2013).
} 
Table 1: Determinants of microinsurance demand

\begin{tabular}{|c|c|c|c|}
\hline \multirow{2}{*}{ Variables } & \multicolumn{3}{|c|}{ Sign of determination } \\
\hline & Positive & Negative & Non-significant \\
\hline \multicolumn{4}{|c|}{ Economic factors } \\
\hline $\begin{array}{l}\text { 1. Price of } \\
\text { insurance } \\
\text { (including } \\
\text { transaction } \\
\text { costs) }\end{array}$ & & \begin{tabular}{|l} 
Price of insurance \\
1. Bauchet (2013) \\
2. Cole et al. (2013) \\
3. Dercon et al. (2012) \\
4. Fitzpatrick et al. (2011) \\
5. Karlan et al. (2012) \\
6. Mobarak and \\
Rosenzweig (2012) \\
7. Thornton et al. (2010) \\
Transaction costs \\
1. Akotey et al. (2011) \\
2. Tadesse and Brans \\
(2012) \\
3. Thornton et al. (2010)
\end{tabular} & $\begin{array}{l}\text { Price of insurance } \\
\text { 1. Gaurav et al. (2011) }\end{array}$ \\
\hline $\begin{array}{l}\text { 2. Wealth } \\
\text { (access to } \\
\text { credit/ } \\
\text { liquidity) } \\
\text { and income }\end{array}$ & $\begin{array}{l}\text { Wealth (Access to } \\
\text { credit }^{16} \text { /liquidity) } \\
\text { 1. Cole et al. (2013) } \\
\text { 2. Giné et al. (2008) } \\
\text { 3. Liu and Myers (2012) } \\
\text { Income } \\
\text { 1. Jutting (2003) }\end{array}$ & $\begin{array}{l}\text { Access to liquidity } \\
\text { 1. Gollier (2003) }\end{array}$ & $\begin{array}{l}\text { Access to credit } \\
\text { 1. Clarke (2011) } \\
\text { 2. Ito and Kono (2010) } \\
\text { 3. Karlan et al. (2012) } \\
\text { Income } \\
\text { 1. Fitzpatrick et al. } \\
\quad \text { (2011) } \\
\text { 2. Thornton et al. (2010) }\end{array}$ \\
\hline \multicolumn{4}{|c|}{ Social and cultural factors } \\
\hline $\begin{array}{l}\text { 3. Risk } \\
\text { aversion }\end{array}$ & 1. Ito and Kono (2010) & $\begin{array}{l}\text { 1. Cole et al. (2013) } \\
\text { 2. Giné et al. (2008) } \\
\text { 3. Giesbert et al. (2011) } \\
\text { 4. Kouame and Komenan } \\
(2012)\end{array}$ & \\
\hline $\begin{array}{l}\text { 4. Non- } \\
\text { performance } \\
\text { and basis } \\
\text { risk }\end{array}$ & & \begin{tabular}{|l} 
Basis risk \\
1. Clarke (2011) \\
2. Mobarak and \\
Rosenzweig (2012) \\
3. Dercon et al. (2011)
\end{tabular} & \\
\hline $\begin{array}{l}\text { 5. Trust and } \\
\text { peer effects }\end{array}$ & $\begin{array}{l}\text { Trust } \\
\text { 1. Basaza et al. (2008) } \\
\text { 2. Cai et al. (2009) } \\
\text { 3. Cole et al. (2013) } \\
\text { 4. Dercon (2012) } \\
\text { 5. Giné et al. (2008) } \\
\text { 6. Patt et al. (2009, 2010) } \\
\text { 7. Tadesse and Brans (2012) } \\
\text { 8. Zhang et al. (2006) } \\
\text { Peer effects } \\
\text { 1. Cai et al. (2011) } \\
\text { 2. Giné et al. (2011) } \\
\text { 3. Karlan et al. (2012) } \\
\text { 4. Morsink and Geurts (2011) }\end{array}$ & & \\
\hline
\end{tabular}

\footnotetext{
${ }^{16}$ Cole et al. (2013) and Giné et al. (2008) relate wealth to access to credit.
} 
Table 1 [Continued]

\begin{tabular}{|c|c|c|c|}
\hline \multirow{2}{*}{ Variables } & \multicolumn{3}{|c|}{ Sign of determination } \\
\hline & Positive & Negative & Non-significant \\
\hline \multicolumn{4}{|l|}{ Economic factors } \\
\hline $\begin{array}{l}\text { 6. Religion/ } \\
\text { fatalism }\end{array}$ & 1. Cole et al. (2011) & & \\
\hline $\begin{array}{l}\text { 7. Financial } \\
\text { literacy }\end{array}$ & $\begin{array}{l}\text { Financial literacy levels } \\
\text { 1. Cole et al. (2013) } \\
\text { 2. Giné et al. (2008) } \\
\text { Financial literacy initiatives } \\
\text { 1. Cai et al. (2011) } \\
\text { 2. Gaurav et al. (2011) } \\
\text { 3. Giné et al. (2011) } \\
\text { Insurance games } \\
\text { 1. Cai and Song (2011) } \\
\text { 2. Norton et al. }(2011) \\
\text { 3. Patt et al. (2009, 2010) } \\
\text { Education } \\
\text { 1. Akter et al. (2008) } \\
\text { 2. Jehu-Appiah et al. (2011) } \\
\text { 3. Jowett (2003) }\end{array}$ & & $\begin{array}{l}\text { Financial literacy levels } \\
\text { 1. Clarke and Kalani } \\
\text { (2012) } \\
\text { Financial literacy } \\
\text { initiatives } \\
\text { 1. Bonan et al. (2012) } \\
\text { 2. Cole et al. (2013) } \\
\text { 3. Dercon et al.(2012) } \\
\text { Education } \\
\text { 1. Cole et al. (2013) } \\
\text { 2. Giné et al. (2008) }\end{array}$ \\
\hline \multicolumn{4}{|c|}{ Structural factors } \\
\hline $\begin{array}{l}\text { 8. Informal risk } \\
\text { sharing }\end{array}$ & $\begin{array}{l}\text { 1. Mobarak and Rosenzweig } \\
\text { (2012) }\end{array}$ & $\begin{array}{l}\text { 1. Jowett (2003) } \\
\text { 2. Landmann et al. (2012) }\end{array}$ & \\
\hline $\begin{array}{l}\text { 9. Quality of } \\
\text { service }\end{array}$ & $\begin{array}{l}\text { 1. Basaza et al. (2008) } \\
\text { 2. De Allegri et al. (2006) } \\
\text { 3. Dong et al. (2009) } \\
\text { 4. Jehu-Appiah et al. (2011) } \\
\text { 5. Nguyen and Knowles } \\
\text { (2010) }\end{array}$ & & \\
\hline $\begin{array}{l}\text { 10. Risk } \\
\text { exposure }\end{array}$ & 1. Arun et al. (2012) & & $\begin{array}{l}\text { 1. Cole et al. (2013) } \\
\text { 2. Galarza and Carter } \\
(2010)\end{array}$ \\
\hline \multicolumn{4}{|c|}{ Personal and demographic factors } \\
\hline 11. Age & $\begin{array}{l}\text { 1. Cao and Zhang (2011) } \\
\text { 2. Chen et al. (2013) } \\
\text { 3. Giesbert et al. (2011) }\end{array}$ & 1. Giné et al. (2008) & 1. Cole et al. (2013) \\
\hline $\begin{array}{l}\text { 12. Gender } \\
\text { (female is } \\
\text { positive) }\end{array}$ & $\begin{array}{l}\text { 1. Chankova et al. (2008) } \\
\text { 2. Nguyen and Knowles } \\
\text { (2010) }\end{array}$ & $\begin{array}{l}\text { 1. } \text { Bonan et al. (2012) } \\
\text { 2. De Allegri et al. (2006) }\end{array}$ & $\begin{array}{l}\text { 1. Thornton et al. } \\
\text { (2010) }\end{array}$ \\
\hline
\end{tabular}

In the following discussion, we systematically review all factors listed in Table 1 . We first present the results for microinsurance, then compare those results with evidence for traditional insurance markets. This is followed by discussion of possible reasons for differences between the two markets. One factor that may be quite relevant is the interconnectedness of various characteristics. For instance, experience with insurance, which 
is affected by price, may play a role in trust, which in turn appears to affect take-up. These factors likely are relevant in the traditional insurance market as well, yet may not be as evident, perhaps due to far different socioeconomic conditions for insureds in that market.

\subsection{Economic factors}

\subsubsection{Price of insurance (including transactions costs)}

Evidence for microinsurance markets: Following standard economic theory, the price of any normal good is expected to be inversely related to demand for that good (or service). Several studies estimate price sensitivity of microinsurance by randomizing discount vouchers or subsidies. Using just such a method, Cole et al. ${ }^{17}$ find significant price sensitivity for rainfall insurance demand in India-specifically, a 10 percent price decline increases the probability of take-up by 10.4-11.6 percent of the baseline take-up rate, indicating a price elasticity of $1.04-1.16$. Mobarak and Rosenzweig ${ }^{18}$ find that a 50 percent price decline relative to the actuarial price increases the probability of take-up by 17.6 percentage points, suggesting a price elasticity of 0.44 , a result strikingly similar to that of Karlan et al. ${ }^{19}$ Likewise, Dercon et al. ${ }^{20}$ find that reductions in price lead to significant effects on health insurance demand, with 20 percent discount vouchers leading to a 12 percentage point increase in probability of purchase, yielding a price elasticity of 0.6 . Gaurav et al. ${ }^{21}$ test the effect of a money-back guarantee for a full refund of the insurance premium if the rainfall insurance policy fails to pay out ${ }^{22}$ and, surprisingly, find no effect on demand. The findings from the studies on price and microinsurance demand are summarized in Table 2.

\footnotetext{
${ }^{17}$ See Cole et al. (2013).

${ }^{18}$ See Mobarak and Rosenzweig (2012).

${ }^{19}$ See Karlan et al. (2012).

${ }^{20}$ See Dercon et al. (2012).

${ }^{21}$ See Gaurav et al. (2011).

${ }^{22}$ The ceiling to the refund was one unit of insurance.
} 
Table 2: Price and its effect on microinsurance demand

\begin{tabular}{|c|c|c|c|c|c|}
\hline $\begin{array}{l}\text { Author } \\
\text { and year }\end{array}$ & $\begin{array}{l}\text { Insurance } \\
\text { type and } \\
\text { location } \\
\end{array}$ & Research design & Price elasticity & $\begin{array}{l}\text { Effect on take-up } \\
\text { rates }\end{array}$ & $\begin{array}{l}\text { Overall take-up } \\
\text { rates }\end{array}$ \\
\hline $\begin{array}{l}\text { Bauchet } \\
\text { (2013) }\end{array}$ & $\begin{array}{l}\text { Term life } \\
\text { insurance; } \\
\text { Mexico }\end{array}$ & $\begin{array}{l}\text { Randomized } \\
\text { removal of } \\
\text { subsidy from a } \\
\text { subsidized } \\
\text { insurance product }\end{array}$ & & $\begin{array}{l}\text { Take-up probability fell } \\
\text { by } 11 \text { percentage points }\end{array}$ & $\begin{array}{l}-69 \% \text { in the } \\
\text { experiment } \\
\text { - 52\% in reality for } \\
\text { the actual product }\end{array}$ \\
\hline $\begin{array}{l}\text { Cole et al. } \\
\text { (2013) }\end{array}$ & $\begin{array}{l}\text { Rainfall } \\
\text { insurance; } \\
\text { Andhra } \\
\text { Pradesh } \\
\text { and } \\
\text { Gujarat, } \\
\text { India }\end{array}$ & $\begin{array}{l}\text { Randomized } \\
\text { treatment varying } \\
\text { discount on } \\
\text { insurance } \\
\text { purchase (5 Rs, } \\
15 \text { Rs, or } 30 \text { Rs) }\end{array}$ & $\begin{array}{l}\text { A } 10 \% \text { price } \\
\text { decline relative to } \\
\text { the actuarial price } \\
\text { leads to a } 10.4- \\
11.6 \% \text { increase in } \\
\text { probability of take- } \\
\text { up }\end{array}$ & $\begin{array}{l}\text { Take-up rates in low } \\
\text { discount: approx. 22- } \\
36 \% \\
\text { Take-up rates in high } \\
\text { discount: approx. } 30- \\
47 \%\end{array}$ & $\begin{array}{l}\text { Approx. 25\% of } \\
\text { treated households } \\
\text { purchased } \\
\text { insurance }\end{array}$ \\
\hline $\begin{array}{l}\text { Dercon et } \\
\text { al. (2012) }\end{array}$ & $\begin{array}{l}\text { Health } \\
\text { insurance; } \\
\text { Nyeri, } \\
\text { Kenya }\end{array}$ & $\begin{array}{l}\text { Randomized } \\
\text { treatment varying } \\
\text { discount on } \\
\text { insurance } \\
\text { purchase }(0 \% \text {, } \\
10 \% \text {, or } 20 \% \\
\text { discount) }\end{array}$ & $\begin{array}{l}\text { A } 20 \% \text { price } \\
\text { decline relative to } \\
\text { the market price } \\
\text { leads to a } 12 \\
\text { percentage point } \\
\text { increase in } \\
\text { probability of } \\
\text { purchasing }\end{array}$ & \begin{tabular}{|l} 
Take-up rates without \\
discount: $10 \%$ \\
Take up rates with $20 \%$ \\
discount: approx. $22 \%$
\end{tabular} & $\begin{array}{l}16 \% \text { of farmers } \\
\text { treated in the study } \\
\text { purchased the } \\
\text { insurance }\end{array}$ \\
\hline $\begin{array}{l}\text { Fitzpatrick } \\
\text { et al. (2011) }\end{array}$ & $\begin{array}{l}\text { Health } \\
\text { insurance; } \\
\text { Managua, } \\
\text { Nicaragua }\end{array}$ & $\begin{array}{l}\text { Randomized } \\
\text { treatment of } 80 \% \\
\text { subsidy on } \\
\text { insurance }\end{array}$ & & $\begin{array}{l}\text { Consider insurance } \\
\text { utilization and retention } \\
6 \% \text { of those insured } \\
\text { were retained } 18 \\
\text { months after subsidies } \\
\text { ended }\end{array}$ & \\
\hline $\begin{array}{l}\text { Gaurav et } \\
\text { al. (2011) }\end{array}$ & $\begin{array}{l}\text { Rainfall } \\
\text { insurance; } \\
\text { Gujarat, } \\
\text { India }\end{array}$ & \begin{tabular}{|l} 
Randomized \\
treatment of \\
money-back \\
guarantee
\end{tabular} & $\begin{array}{l}\text { Demand increases } \\
\text { by } 6.9 \text { percentage } \\
\text { points for those } \\
\text { treated compared } \\
\text { to control group }\end{array}$ & $\begin{array}{l}6.3 \% \text { take-up rates in } \\
\text { control group } \\
12.7 \% \text { take-up rates in } \\
\text { the subgroup offered } \\
\text { money-back guarantee }\end{array}$ & $\begin{array}{l}11.4 \% \text { overall take- } \\
\text { up rates (including } \\
\text { treated and control } \\
\text { households) }\end{array}$ \\
\hline $\begin{array}{l}\text { Karlan et } \\
\text { al. (2012) }\end{array}$ & $\begin{array}{l}\text { Rainfall } \\
\text { insurance; } \\
\text { northern } \\
\text { Ghana }\end{array}$ & $\begin{array}{l}\text { Randomized } \\
\text { treatment varying } \\
\text { cash grant and } \\
\text { insurance grant }\end{array}$ & $\begin{array}{l}\text { A } 50 \% \text { price } \\
\text { decline relative to } \\
\text { the actuarial price } \\
\text { increases } \\
\text { probability of take- } \\
\text { up by } 31 \% \text { points }\end{array}$ & $\begin{array}{l}\text { Take-up rates at market } \\
\text { price: } 11 \% \\
\text { Take up rates in } 50 \% \\
\text { discount: approx. } 42 \% \\
\text { Take up rates in } 75 \% \\
\text { discount: approx. } 67 \%\end{array}$ & $\begin{array}{l}43 \% \text { of treated } \\
\text { households } \\
\text { purchased } \\
\text { insurance }\end{array}$ \\
\hline $\begin{array}{l}\text { Mobarak } \\
\text { and } \\
\text { Rosenzweig } \\
\text { (2012) }\end{array}$ & $\begin{array}{l}\text { Rainfall } \\
\text { insurance; } \\
\text { Uttar } \\
\text { Pradesh, } \\
\text { Andhra } \\
\text { Pradesh, } \\
\text { and Tamil } \\
\text { Nadu, } \\
\text { India } \\
\end{array}$ & $\begin{array}{l}\text { Randomized } \\
\text { treatment varying } \\
\text { price of insurance } \\
\text { product }(0 \%, \\
10 \%, 50 \% \text {, or } \\
75 \% \text { discount) }\end{array}$ & $\begin{array}{l}\text { A } 50 \% \text { price } \\
\text { decline relative to } \\
\text { the actuarial price } \\
\text { increases the } \\
\text { probability of take- } \\
\text { up by } 17.6 \\
\text { percentage points }\end{array}$ & $\begin{array}{l}\text { Take-up rates at market } \\
\text { price }^{23}: 20 \% \\
\text { Take up rates in } 50 \% \\
\text { discount: approx. } 38 \% \\
\text { Take up rates in } 75 \% \\
\text { discount: approx. } 62 \%\end{array}$ & $\begin{array}{l}\text { Approx. } 40 \% \text { of } \\
\text { treated households } \\
\text { purchased } \\
\text { insurance }\end{array}$ \\
\hline $\begin{array}{l}\text { Thornton et } \\
\text { al. (2010) }\end{array}$ & $\begin{array}{l}\text { Health } \\
\text { insurance; } \\
\text { Managua, } \\
\text { Nicaragua }\end{array}$ & $\begin{array}{l}\text { Randomized } \\
\text { treatment of 6- } \\
\text { month subsidy } \\
\text { worth approx. } \\
\text { USD 96 }\end{array}$ & & $\begin{array}{l}\text { Approx. } 30 \% \text { of those } \\
\text { awarded a } 6 \text {-month } \\
\text { subsidy enrolled (take- } \\
\text { up of } 0 \% \text { in control } \\
\text { group) }\end{array}$ & $\begin{array}{l}\text { - Overall take-up } \\
\text { was } 20.3 \% \\
\text { - Low retention } \\
\text { rates: only } 10 \% \text { of } \\
\text { enrolees enrolled } \\
\text { after one year }\end{array}$ \\
\hline
\end{tabular}

\footnotetext{
${ }^{23}$ For the state of Tamil Nadu only.
} 
Most studies on insurance demand use premiums, in one form or another, as the 'price' variable but, in the 'real world', there are other transaction costs to buying insurance, such as the time and effort required for policy purchase/renewal and claim filing. ${ }^{24}$ Thornton et al. ${ }^{25}$ identify cost of time and effort as an important reason for choosing not to enrol in health insurance, even when it is subsidized. Allowing workers to sign up directly at their place of employment, rather than miss a day of work due to the process, led to a 30 percentage point higher take-up.

While reducing the price of microinsurance is likely to increase demand, overall take-up rates may remain low. Cole et al. ${ }^{26}$ find that even when prices are significantly below actuarially fair prices, fewer than half of households purchase rainfall insurance. Thornton et al. ${ }^{27}$ observe that randomized subsidies increase take-up of health insurance, yet only 30 percent of those awarded a six-month subsidy enrol in the plan. Some evidence suggests that lack of demand is associated with lack of experience with insurance. In response, Cole et al. ${ }^{28}$ recommend heavy initial subsidies. The influence of subsidies, however, may be perverse. Thornton et al., ${ }^{29}$ Fitzpatrick et al., ${ }^{30}$ and Bauchet $^{31}$ find that retention rates drop significantly following expiration of subsidies, running counter to the notion that familiarity will improve results. Furthermore, some instances of subsidy use appear to break the informal support mechanisms (often referred to as 'solidarity') that existed before insurance products were introduced, exacerbating the situation. ${ }^{32}$

\footnotetext{
${ }^{24}$ See De Bock and Gelade (2012).

25 See Thornton et al. (2010).

${ }^{26}$ See Cole et al. (2013).

${ }^{27}$ See Thornton et al. (2010).

${ }^{28}$ See Cole et al. (2013).

${ }^{29}$ See Thornton et al. (2010).

${ }^{30}$ See Fitzpatrick et al. (2011).

${ }^{31}$ See Bauchet (2013).

${ }^{32}$ See Latortue (2006).
} 
Regarding transaction costs, several studies posit that microfinance institutions (MFI) could play a role in lowering such costs. ${ }^{33}$ Whether this will be the case appears to depend on ease of access to the MFI location, trust in the MFI, and, sometimes, the ability to bundle credit with insurance purchases. Thornton et al. ${ }^{34}$ find a slight negative effect (5.4 percentage points) on enrolment among participants assigned to an MFI rather than to a government agency. Qualitative data gathered through participant surveys suggest that administrative challenges in working with these particular MFIs may increase rather than decrease transaction costs. Other studies indicate that access to agents at work, the availability of periodic rather than lump-sum payments, and similar factors are relevant to demand. ${ }^{35}$

Comparison with evidence for traditional insurance: As expected, price also affects traditional insurance demand. ${ }^{36}$ Evidence from developed markets generally shows a price elasticity of demand for insurance of .2 to $.4,{ }^{37}$ which is lower than that observed in microinsurance markets. Moreover, transaction costs are also important barriers to enrolment in traditional markets. Low take-up rates of public health insurance in the United States, for instance, have been associated with burdensome transaction costs. ${ }^{38}$

Price is a relative factor, however, and we anticipate that there will be significant differences between traditional and microinsurance markets in the matter of price. Although premiums are 'low' in the microinsurance market, even this cost when compared with income and/or available assets may well be high for the target population. Furthermore, the portion of the premium associated with loss costs tends to be lower in microinsurance than in similar

\footnotetext{
33 See Akotey et al. (2011); Tadesse and Brans (2012).

${ }^{34}$ See Thornton et al. (2010).

${ }^{35}$ See Akter et al. 2008.

${ }^{36}$ See Babbel (1985); Browne and Kim (1993); Mantis and Farmer (1968); for a more comprehensive review, see Zietz (2003).

${ }^{37}$ See Marquis et al. (2004).

${ }^{38}$ See Aizer (2007); Baicker et al. (2012); Bansak and Raphael (2006).
} 
traditional insurance products, given the effect of fixed costs in setting premiums. To the extent that consumers are aware of these differences, theory would suggest lower demand in the microinsurance market as a result.

\subsubsection{Wealth (access to credit/ liquidity) and income}

Evidence for microinsurance markets: Several studies show a positive relationship between wealth ${ }^{39}$ and microinsurance purchase. The underlying theory is that wealth provides higher levels of liquidity and/or access to credit so that the purchase of insurance is feasible. Access to credit refers to borrowing opportunities; liquidity refers to availability of assets beyond what is needed to cover basic household expenses. Giné et al. ${ }^{40}$ find that take-up rates for rainfall insurance in rural India are higher among wealthier households. Similarly, in a field experiment in India, Cole et al. $^{41}$ find that wealthier households are more likely to purchase rainfall insurance. In both instances, less-wealthy households are believed to have little to no margin for insurance purchase after paying for agricultural needs at the start of the growing season (which is also the time when insurance would need to be purchased). These households may want insurance, but simply do not have the resources to buy insurance at the time when premiums are due.

The wealth effect in the microinsurance market, therefore, appears distinct from the effect in traditional markets, where wealth often translates into greater levels of potential loss, leading to more insurance being purchased. In microinsurance markets, wealth is instead a signal of access to credit (and/or liquidity). A priori it is not clear whether the effect of access to credit on demand is positive or negative. On the one hand, households without access to

\footnotetext{
${ }^{39}$ Wealth is measured differently across studies, ranging from total number of livestock and total land owned to creating an index using number of durable goods such as TV, radio, bicycle, etc.

${ }^{40}$ See Giné et al. (2008).

${ }^{41}$ See Cole et al. (2013).
} 
credit have less ability to smooth consumption in case of a shock and they thus may place higher value on insurance as a means to reduce income volatility. ${ }^{42}$ Gollier's ${ }^{43}$ theoretical model follows this reasoning. On the other hand, households lacking access to credit may not have funds enough to buy insurance even though a shock may be more damaging to them than to households less constrained. Cole et al. ${ }^{44}$ find support for this second line of thought, observing that take-up increases by 140 percent when households are given enough cash to buy one policy. The authors speculate as to the effects on take-up of even higher levels of cash disbursement.

Access to credit/liquidity alone, however, will not necessarily raise microinsurance demand significantly. Clarke ${ }^{45}$ shows that even for farmers who are not credit constrained and who are offered actuarially fair premiums, basis risk causes them to purchase less than full insurance. Other scholars, such as Ito and Kono ${ }^{46}$ and Karlan et al., ${ }^{47}$ find little or no effect of credit constraints on microinsurance demand. The literature dealing with the effect of access to credit/liquidity on microinsurance demand is summarized in Table 3. To address the problem of credit constraints, Liu and Myers ${ }^{48}$ propose an insurance design where farmers can delay payment of the premium until the end of the insured period. Empirical results of such a design are yet to be assessed.

\footnotetext{
${ }^{42}$ See Giné et al. (2008).

${ }^{43}$ See Gollier (2003).

${ }^{44}$ See Cole et al. (2013).

${ }^{45}$ See Clarke (2011).

${ }^{46}$ See Ito and Kono (2010).

${ }^{47}$ See Karlan et al. (2012).

${ }^{48}$ See Liu and Myers (2012).
} 
Table 3: Access to credit/liquidity and its effect on demand

\begin{tabular}{|c|c|c|c|c|}
\hline $\begin{array}{l}\text { Author } \\
\text { and year }\end{array}$ & $\begin{array}{l}\text { Insurance type } \\
\text { and location }\end{array}$ & Research design & Effects on take-up rates & $\begin{array}{l}\text { Overall take-up } \\
\text { rates }\end{array}$ \\
\hline $\begin{array}{l}\text { Clarke } \\
(2011)\end{array}$ & $\begin{array}{l}\text { Index insurance } \\
\text { (theoretical) }\end{array}$ & Theoretical model & $\begin{array}{l}\text { In the presence of basis risk, } \\
\text { even those with access to } \\
\text { credit will not buy insurance }\end{array}$ & \\
\hline $\begin{array}{l}\text { Cole et al. } \\
\text { (2013) }\end{array}$ & $\begin{array}{l}\text { Rainfall } \\
\text { insurance; } \\
\text { Andhra Pradesh } \\
\text { and Gujarat, India }\end{array}$ & $\begin{array}{l}\text { Randomized } \\
\text { treatment of high } \\
\text { cash rewards } \\
\text { (enough to buy } \\
\text { one policy) }\end{array}$ & $\begin{array}{l}\text { Take-up for one policy } \\
\text { increases take-up by } 140 \%\end{array}$ & $\begin{array}{l}\text { - One quarter of } \\
\text { treated households } \\
\text { in the study villages } \\
\text { buy insurance } \\
\text { - } 0 \% \text { take-up in the } \\
\text { untreated general } \\
\text { population in the } \\
\text { same villages }\end{array}$ \\
\hline $\begin{array}{l}\text { Giné et al. } \\
\text { (2008) }\end{array}$ & $\begin{array}{l}\text { Rainfall } \\
\text { insurance; } \\
\text { Andhra Pradesh, } \\
\text { India }\end{array}$ & Household survey & $\begin{array}{l}\text { Regression estimates show } \\
\text { that households without } \\
\text { access to credit have lower } \\
\text { take-up rates }\end{array}$ & \\
\hline $\begin{array}{l}\text { Gollier } \\
\text { (2003) }\end{array}$ & $\begin{array}{l}\text { Dynamic model } \\
\text { of insurance }\end{array}$ & Theoretical model & $\begin{array}{l}\text { Liquidity constraints } \\
\text { increase demand for } \\
\text { insurance }\end{array}$ & \\
\hline $\begin{array}{l}\text { Ito and } \\
\text { Kono } \\
(2010)\end{array}$ & $\begin{array}{l}\text { Health insurance; } \\
\text { Karnataka, India }\end{array}$ & Household survey & $\begin{array}{l}\text { Regression estimates show } \\
\text { negative (but not significant) } \\
\text { association between credit } \\
\text { constraints and take-up rates }\end{array}$ & \\
\hline $\begin{array}{l}\text { Jutting } \\
(2003)\end{array}$ & $\begin{array}{l}\text { Health insurance; } \\
\text { Thies, Senegal }\end{array}$ & Household survey & $\begin{array}{l}\text { Lack of funds cited as a } \\
\text { major barrier for } \\
\text { nonparticipation }\end{array}$ & \\
\hline $\begin{array}{l}\text { Karlan et } \\
\text { al. (2012) }\end{array}$ & $\begin{array}{l}\text { Rainfall } \\
\text { insurance; } \\
\text { northern Ghana }\end{array}$ & $\begin{array}{l}\text { Randomized } \\
\text { treatment varying } \\
\text { cash grant and } \\
\text { insurance grant }\end{array}$ & $\begin{array}{l}\text { Insignificant effect on take- } \\
\text { up rates }\end{array}$ & $\begin{array}{l}\text { 43\% households } \\
\text { purchased insurance }\end{array}$ \\
\hline $\begin{array}{l}\text { Liu and } \\
\text { Myers } \\
\text { (2012) }\end{array}$ & $\begin{array}{l}\text { Dynamic model } \\
\text { of agricultural } \\
\text { insurance }\end{array}$ & Theoretical model & $\begin{array}{l}\text { Liquidity constraints reduce } \\
\text { demand for insurance; } \\
\text { deferred payment relaxes } \\
\text { such constraints }\end{array}$ & \\
\hline
\end{tabular}

Income also is expected to affect a household's ability to afford insurance, yet it is especially difficult to measure in societies where wage income is negligible and self-reported measures of income are likely to be unreliable. ${ }^{49}$ Studies that measure income's effect on demand find either a positive or no effect. Jutting ${ }^{50}$ observes that low income plays a key role in nonparticipation in a community-based health insurance scheme in rural Senegal;

\footnotetext{
${ }^{49}$ See Morris et al. (2000).

${ }^{50}$ See Jutting (2003); this study looks at whether insurance makes members better off than non-members. While it does not specifically look at insurance demand, it asks non-members the reason for not taking up insurance.
} 
Fitzpatrick et al. ${ }^{51}$ and Thornton et al. ${ }^{52}$ find no effect of income on insurance take-up rates. These results may reflect the high degree of correlation between income and other household characteristics. $^{53}$

Comparison with evidence for traditional insurance: Research on traditional insurance demand tends to consider wealth and income as proxies for loss potential. That is, the more wealth and/or income, the greater the potential loss and, therefore, the greater the demand for insurance. The opposite could be true, however, assuming decreasing relative risk aversion. ${ }^{54}$ Under this theory, the greater the wealth, the less the individual will be concerned over any specific potential shock.

Both income and wealth are found to be relevant in traditional insurance markets, and this result is supported by theory. ${ }^{55}$ Outreville's ${ }^{56}$ review shows that greater levels of national income (and, in a few studies, wealth) are associated with higher insurance penetration rates. Because of multicollinearity issues, most studies include either income or wealth in the analysis, rather than both simultaneously.

Wealth appears to affect the microinsurance and traditional insurance markets differently, although the expected sign of the effect is positive in both cases. In the traditional market, wealth (and/or income) typically represents potential loss. The larger that potential loss, the higher the level of insurance purchased. As discussed above, an alternative hypothesis associates lower relative risk aversion with increasing wealth, but most empirical

\footnotetext{
${ }^{51}$ See Fitzpatrick et al. (2011).

52 See Thornton et al. (2010).

53 See Thornton et al. (2010).

${ }^{54}$ See Mossin (1968).

${ }^{55}$ For a more comprehensive review, see Zietz (2003).

${ }^{56}$ See Outreville (2013).
} 
findings support the loss potential theory. Within microinsurance markets, greater levels of wealth (and/or access to credit markets) provide a means to pay an insurance premium. Lower-income individuals may actually have a greater need for insurance than the more wealthy because of the relative influence of the same type of shock, but those with lower incomes may suffer resource constraints that make insurance purchase infeasible. Even so, resource constraints do not appear to fully explain the low take-up rates in emerging markets.

\subsection{Social and cultural factors}

\subsubsection{Risk aversion}

Evidence for microinsurance: In contrast with the predictions of expected utility theory, studies in microinsurance markets show a negative association between risk aversion and demand. Risk aversion is generally measured using experimental designs where subjects choose between a safe option and some risky lotteries with varying expected outcomes and variances. ${ }^{57}$ Giné et al. ${ }^{58}$ and Cole et al. ${ }^{59}$ (rainfall insurance in India), Kouame and Komenan ${ }^{60}$ (crop insurance in Cote D’Ivoire), and Giesbert et al. ${ }^{61}$ (micro life insurance in Ghana) find that more risk-averse households are less likely to purchase insurance.

Several possibilities have been proposed to explain this consistent observation that risk aversion and insurance purchase are negatively related. One is that most experimental studies measure risk aversion by using lotteries in which only gains or the status quo are possible. Several scholars test for the effect of omitting the loss domain. Ito and Kono ${ }^{62}$ find weak empirical support for the prospect theory contention that people tend toward risk loving in

\footnotetext{
${ }^{57}$ There are several different risk elicitation procedures, e.g., Binswanger (1981); Holt and Laury (2002).

58 See Giné et al. (2008).

${ }^{59}$ See Cole et al. (2013).

${ }^{60}$ See Kouame and Komenan (2012).

${ }^{61}$ See Giesbert et al. (2011).

62 See Kahneman and Tversky (1979).
} 
losses. Dercon et al. ${ }^{63}$ observe differences in risk attitudes across the two domains, but do not find those attitudes to be significant in regard to insurance purchase.

Other interpretations suggest that households view insurance as risky ${ }^{64}$ or that potential insureds have a limited understanding of the product. ${ }^{65}$ Factors such as price uncertainty associated with crop insurance ${ }^{66}$ and the possibility of non-performance, evident for example in basis risk associated with rainfall insurance, ${ }^{67}$ cause individuals to view insurance as risky. These factors are discussed further below.

Comparison with evidence for traditional insurance: Empirical evidence on the relationship between risk aversion and insurance demand in developed markets also is ambiguous. ${ }^{68}$ Furthermore, according to Cardenas and Carpenter's ${ }^{69}$ literature review, there is no empirical evidence supporting the idea that poor people in developing countries have higher or lower risk aversion than richer people in developed countries. It may well be that some of what is being discovered in the microinsurance context will assist in understanding the relationship between risk aversion and insurance purchase decisions in the traditional markets.

\subsubsection{Non-performance and basis risk}

Evidence for microinsurance: As just noted, one explanation offered for the inverse relationship between risk aversion and microinsurance demand is the possibility of non-

\footnotetext{
${ }^{63}$ See Dercon et al. (2011).

${ }^{64}$ See Giné et al. (2008); Giesbert et al. (2011).

65 See Cole et al. (2013).

${ }^{66}$ See Kouame and Komenan (2012).

${ }^{67}$ See Clarke (2011).

${ }^{68}$ See Outreville (2013); Zietz (2003).

${ }^{69}$ See Cardenas and Carpenter (2008).
} 
performance $^{70}$, including basis risk ${ }^{71}$ in microinsurance products. Dercon et al. ${ }^{72}$ observe that expectations of non-performance influence demand for microinsurance. Non-performance may arise from contract exclusions, insurer bankruptcy, and other factors. One factor given specific attention in the literature is that of basis risk, which can be significant in indexed crop coverage. Basis risk here refers to the situation when insurance payouts are not perfectly correlated with underlying losses. ${ }^{73}$

Clarke $^{74}$ demonstrates that low demand for insurance can be explained by risk aversion in the presence of basis risk. Similarly, in a test involving randomly placed rainfall gauges and offers of index insurance to Indian farmers, Mobarak and Rosenzweig ${ }^{75}$ find that for every kilometre increase in a farmer's perceived distance of the weather station (a proxy of basis risk), demand falls by 6.4 percent. Non-performance, including that due to basis risk, is sometimes offered as a reason for a distrust of insurance, which in turn affects demand. The issue of trust is considered below. Mobarak and Rosenzweig ${ }^{76}$ assert that the distance to the rainfall station is unlikely to proxy for 'trust' itself, and conclude that basis risk is a separate issue that needs to be addressed when seeking higher microinsurance take-up rates.

Comparison with evidence for traditional insurance: In terms of contractual nonperformance risk, Wakker et al. ${ }^{77}$ show that even a small probability that the client will not receive a payout has a negative impact on insurance demand in traditional markets. These results are consistent with evidence suggesting that insurers can extract higher prices by

\footnotetext{
${ }^{70}$ See Doherty and Schlesinger (1990).

${ }^{71}$ See Dercon et al. (2011).

72 See Dercon et al. (2011).

${ }^{73}$ For instance, a farmer who purchases indexed crop insurance could receive payment even when crops are not damaged and, importantly, might be denied compensation even when crops are lost. Payment is related to some underlying condition, such as the level of rainfall, rather than actual loss experience.

${ }^{74}$ See Clarke (2011).

${ }^{75}$ See Mobarak and Rosenzweig (2012).

${ }^{76}$ See Mobarak and Rosenzweig (2012).

${ }^{77}$ See Wakker et al. (1997).
} 
demonstrating lower default risk. ${ }^{78}$ Moreover, the quality of the legal and regulatory environment has a significant effect on insurance markets in developed countries. ${ }^{79}$ Lack of appropriate data, however, makes analysis of the legal and regulatory environment difficult; the few studies that have assessed the impact of legal environment on demand at the macro level in the traditional markets find it to be positive and significant. ${ }^{80}$

\subsubsection{Trust and peer effects}

Evidence for microinsurance: A second aspect of 'non-performance' risk may manifest itself as lack of trust, an issue of potential importance throughout the globe, yet one that appears to be particularly relevant for emerging economies. Based on qualitative responses, Giné et al. ${ }^{81}$ note that trust in the insurance provider is a key determinant of rainfall insurance demand in India. Similarly, Cole et al. ${ }^{82}$ find that households in India do not fully trust or understand insurance, and that their demand is 36 percent higher when there is a recommended (i.e., trusted) insurance educator involved in the purchase process. Cai et al. ${ }^{83}$ and Zhang et al. ${ }^{84}$ find that lack of trust in government-subsidized insurance in China is a significant barrier to participation. Similarly, Basaza et al. ${ }^{85}$ find that lack of trust was an important reason for low enrolment in community health insurance in Uganda.

Trust in insurance contracts is especially relevant in environments with weak legal systems for enforcing payment of valid claims. ${ }^{86}$ In developing countries with weak rule of

\footnotetext{
${ }^{78}$ See Sommer (1996).

${ }^{79}$ See Outreville (2013).

${ }^{80}$ See Outreville (2013); Beck and Webb (2003).

${ }^{81}$ See Giné et al. (2008).

${ }^{82}$ See Cole et al. (2013).

${ }^{83}$ See Cai et al. (2009); Cole et al. (2013).

${ }^{84}$ See Zhang et al. (2006).

${ }^{85}$ See Basaza et al. (2008).

${ }^{86}$ See Cole et al. (2013).
} 
law, the implication is a negative impact on insurance demand; ${ }^{87}$ however, we are unaware of any work empirically analysing this relationship in the microinsurance context.

One method of building trust is through participatory games that teach players how insurance works. Patt et al. ${ }^{88}$ find that this method seemed to build trust when used with a group of farmers. Results from studies testing the effect of trust on microinsurance demand are summarized in Table 4.

Table 4: Effect of trust on microinsurance demand

\begin{tabular}{|c|c|c|c|c|}
\hline $\begin{array}{l}\text { Author } \\
\text { and year }\end{array}$ & $\begin{array}{l}\text { Insurance type } \\
\text { and location }\end{array}$ & Research design & Effects on take-up rates & Overall take-up rates \\
\hline $\begin{array}{l}\text { Basaza et } \\
\text { al. (2008) }\end{array}$ & $\begin{array}{l}\text { Health } \\
\text { insurance; } \\
\text { Uganda }\end{array}$ & $\begin{array}{l}\text { Focus group } \\
\text { discussions and in- } \\
\text { depth interviews }\end{array}$ & $\begin{array}{l}\text { Lack of trust cited as a } \\
\text { major barrier to take-up }\end{array}$ & \\
\hline $\begin{array}{l}\text { Cai et al. } \\
\text { (2009) }\end{array}$ & $\begin{array}{l}\text { Sow insurance; } \\
\text { southwestern } \\
\text { China }\end{array}$ & $\begin{array}{l}\text { Randomized natural } \\
\text { field experiment } \\
\text { using participation in } \\
\text { government-run } \\
\text { scheme and subsidy } \\
\text { as proxies for trust in } \\
\text { government- } \\
\text { sponsored programs }\end{array}$ & $\begin{array}{l}\text { Just over } 50 \% \text { take-up } \\
\text { rate of heavily subsidized } \\
\text { insurance in control } \\
\text { group village, suggesting } \\
\text { lack of trust in the } \\
\text { program }\end{array}$ & $\begin{array}{l}50 \% \text { take-up rate for } \\
\text { heavily subsidized } \\
\text { insurance }\end{array}$ \\
\hline $\begin{array}{l}\text { Cole et al. } \\
\text { (2013) }\end{array}$ & $\begin{array}{l}\text { Rainfall } \\
\text { insurance; } \\
\text { Andhra Pradesh } \\
\text { and Gujarat, } \\
\text { India }\end{array}$ & $\begin{array}{l}\text { Randomized } \\
\text { treatment of } \\
\text { households via visits } \\
\text { by insurance educator } \\
\text { who is recommended } \\
\text { to the household by a } \\
\text { trusted local agent }\end{array}$ & $\begin{array}{l}\text { Demand is } 36 \% \text { higher } \\
\text { with a recommended } \\
\text { insurance educator }\end{array}$ & $\begin{array}{l}\text { - One-quarter of treated } \\
\text { households in the } \\
\text { study villages buy } \\
\text { insurance } \\
\text { - 0\% take-up in the } \\
\text { untreated general } \\
\text { population in the } \\
\text { same villages }\end{array}$ \\
\hline $\begin{array}{l}\text { Dercon et } \\
\text { al. (2011) }\end{array}$ & $\begin{array}{l}\text { Health } \\
\text { insurance; } \\
\text { Nyeri, Kenya }\end{array}$ & Trust game in the lab & $\begin{array}{l}\text { Decision to purchase } \\
\text { insurance depends on the } \\
\text { credibility of the insurer }\end{array}$ & N/A \\
\hline $\begin{array}{l}\text { Giné et al. } \\
\text { (2008) }\end{array}$ & $\begin{array}{l}\text { Rainfall } \\
\text { insurance; } \\
\text { Andhra Pradesh, } \\
\text { India }\end{array}$ & Household survey & $\begin{array}{l}\text { Probability of insurance } \\
\text { participation increases by } \\
\text { a factor of } 8 \text { with trust in } \\
\text { the insurance vendor }\end{array}$ & \\
\hline $\begin{array}{l}\text { Zhang et } \\
\text { al. (2006) }\end{array}$ & $\begin{array}{l}\text { Health } \\
\text { insurance; } \\
\text { China }\end{array}$ & Household survey & $\begin{array}{l}\text { Lack of trust noted as a } \\
\text { barrier to take-up }\end{array}$ & $\begin{array}{l}\text { Less than } 50 \% \text { take-up } \\
\text { rates in the sample }\end{array}$ \\
\hline
\end{tabular}

\footnotetext{
${ }^{87}$ See Outreville (2013).

${ }^{88}$ See Patt et al. (2009, 2010).
} 
Peer influence is sometimes related to trust. Morsink and Geurts ${ }^{89}$ find that clients of a typhoon-related microinsurance program in the Philippines rely on the claim payout experiences of trusted peers. Likewise, Karlan et al. ${ }^{90}$ find that demand for insurance in following years increases not only when a farmer has himself or herself received an insurance payout, but also when others in the farmer's social network have received a payout.

Several studies investigate the usefulness of social networks in disseminating insurance information. Giné et al. ${ }^{91}$ find that financial literacy materials are efficacious in encouraging take-up when farmers' social contacts are involved. Cai et al. ${ }^{92}$ find that social networks have a large and significant effect on insurance take-up decisions in China. In contrast, Dercon et al. ${ }^{93}$ assess the impact of peer referrals for health insurance participation in Kenya and find that the referral incentive has a negative influence on insurance demand relative to the basic marketing treatment. The authors suggest that the negative impact of peer referrals may be due to distrust of insurance sales staff. Hence, trust in one's peers seems to be an important factor in their influence on demand.

Comparison with evidence for traditional insurance: There is some, albeit limited, evidence that peer effects are relevant for insurance decisions in the traditional market. Sorensen finds that there is some effect of co-workers' decisions on one's own decision to purchase health insurance in the United States. ${ }^{94}$

\footnotetext{
${ }^{89}$ See Morsink and Geurts (2011).

${ }^{90}$ See Karlan et al. (2012).

${ }^{91}$ See Giné et al. (2011).

${ }^{92}$ See Cai et al. (2011).

${ }^{93}$ See Dercon et al. (2012).

${ }^{94}$ See Sorensen (2006).
} 


\subsubsection{Religion/fatalism}

Evidence for microinsurance: Religion sometimes is considered to be related to risk attitudes as well as to a sense of cohesion within a community. A related factor, 'fatalism', is a measure of the extent to which individuals view events as outside of their control. Gheyssens and Gunther ${ }^{95}$ find that those with strong faith tend to rely more on God, resulting in more risk-taking. The authors study only risk aversion, not insurance demand, but their results may have implications for insurance demand. In India, fatalism is associated with greater use of insurance but the study does not evaluate insurance demand specifically. ${ }^{96}$ Cole et al. ${ }^{97}$ also test for group affiliation effects through advertisements that highlight one's similarity to or difference from others in terms of religion. They find that such affiliations affect insurance demand.

Comparison with evidence for traditional insurance: Various studies test for the effects of religion on risk attitudes in traditional markets. Some find only a small effect on risk aversion, ${ }^{98}$ while others find more robust results, with more religious people demonstrating higher levels of risk aversion. ${ }^{99}$ Several cross-country studies assess insurance demand in Islamic countries, finding a negative correlation between insurance demand and religion. ${ }^{100}$ The effects of religion on risk attitudes and insurance demand is a fruitful area for future research.

\footnotetext{
${ }^{95}$ See Gheyssens and Gunther (2012).

${ }^{96}$ See Cole et al. (2011).

${ }^{97}$ See Cole et al. (2013).

${ }^{98}$ See Eisenhauer and Halek (1999).

${ }^{99}$ See Bartke and Schwarze (2008); Noussair et al. (2012).

100 See Beck and Webb (2003); Browne and Kim (1993); Feyen et al. (2011).
} 


\subsubsection{Financial literacy}

Evidence for microinsurance: Financial literacy is expected to increase insurance demand. A commonly used measurement is a set of questions developed by Lusardi and Mitchell ${ }^{101}$ that tests understanding of basic financial concepts such as interest rate compounding, inflation, and risk diversification. Cole et al. ${ }^{102}$ find that demand is higher among households with higher financial literacy. Cai and Song ${ }^{103}$ and Norton et al. ${ }^{104}$ find increased insurance take-up following insurance games. Giné et al. ${ }^{105}$ find that lack of product understanding is the second most (after insufficient resources) commonly cited reason for not purchasing insurance. A number of studies, however, question the link between financial literacy and demand. For example, in a study of Ethiopians, Clarke and Kalani ${ }^{106}$ find no impact of financial literacy on insurance demand. Furthermore, Dercon et al. ${ }^{107}$ (Kenya), Bonan et al. ${ }^{108}$ (Senegal), and Cole et al. ${ }^{109}$ (India) all included financial literacy modules as part of their experiments. None of them observe an effect of these modules on insurance demand.

Distinct from financial literacy, education has been posited as a relevant factor in insurance demand. While education has been used as a proxy for financial literacy when no other measure is available, the two are considered different from one another. ${ }^{110}$ Empirical evidence suggests that the link between education and microinsurance demand is ambiguous: some find that more educated respondents are more likely to take up insurance; ${ }^{111}$ others find

\footnotetext{
$\overline{101}$ See Lusardi and Mitchell (2006).

${ }^{102}$ See Cole et al. (2013).

103 See Cai and Song (2011).

${ }^{104}$ See Norton et al. (2011).

105 See Giné et al. (2008).

106 See Clarke and Kalani (2012).

${ }^{107}$ See Dercon et al. (2012).

${ }^{108}$ See Bonan et al. (2012).

109 See Cole et al. (2013).

110 See Lusardi and Mitchell (2006).

${ }^{111}$ See Akter et al. (2008); Chen et al. (2013); Jehu-Appiah et al. (2011); Jowett (2003).
} 
no significant association between education and insurance uptake once accounting for financial literacy. ${ }^{112}$

Comparison with evidence for traditional insurance: There is quite an extensive literature on the association between financial literacy and other financial services such as savings, retirement funds, and the like, but studies on its relationship with insurance demand in developed markets is limited. ${ }^{113}$ Nevertheless, the existing evidence indicates a positive association between financial literacy and insurance demand. ${ }^{114}$ Most of the empirical papers on developed insurance markets show a strong positive association between education and insurance demand; ${ }^{115}$ however, some studies find no significant relation ${ }^{116}$ and others find a negative effect. ${ }^{117}$ There may be various reasons for these results, including differences in rigor across educational systems, confounding effects of education with other factors such as income and wealth, and cultural aspects involving how education influences custom. Further study on both education and literacy is warranted.

\subsection{Structural factors}

\subsubsection{Informal risk sharing}

Evidence for microinsurance: Informal risk-sharing networks are an important part of coping with risk in developing countries. ${ }^{118}$ Furthermore, the level of informal risk-sharing in a social network can have a significant impact on demand for formal risk-sharing mechanisms such as insurance. Jowett ${ }^{119}$ finds that individuals living in highly interconnected

\footnotetext{
${ }^{112}$ See Giné et al. (2008); Cole et al. (2013).

${ }^{113} \mathrm{Xu}$ and Zia (2012) note that financial literacy affect insurance take-up in lower-income countries.

114 See Hecht and Hanewald (2010); Cappelletti et al. (2012).

115 See Truett and Truett (1990); Li et al. (2007).

116 See Browne and Kim (1993).

${ }^{117}$ For a comprehensive list of studies, see Zietz (2003).

118 See Fafchamps and Lund (2003); Morduch (1999).

${ }^{119}$ See Jowett (2003).
} 
communities in Vietnam are far less likely to purchase government health insurance. The findings suggest that strong informal networks may crowd out government interventions.

Mobarak and Rosenzweig ${ }^{120}$ explore the hypothesis that risk-sharing networks could actually complement index insurance in the presence of basis risk. They find that in communities with strong informal risk-sharing systems, index insurance can be attractive. When the formal indexed policy makes a payout, the payment appears to become a part of the community's perceived overall resources, and informal mechanisms then likely spread those payouts to the farmers who experienced the largest losses. Essentially, the community undertakes the administrative task of delivering the insurance payment to the individuals who suffered loss.

Comparison with evidence for traditional insurance: The use of mutuals and cooperatives in the early stages of insurance market development, especially when mutuals were assessable, ${ }^{121}$ was similar to today's informal risk-sharing systems in emerging economies. As assessable mutuals are now rare, perhaps social security systems are the closest relative to informal risk-sharing strategies. Social security is a means by which governments are able to provide (and enhance) the sort of intergenerational informal risk sharing previously common in agrarian societies. By providing protection against health, disability, and mortality risks, social security is expected to have a negative impact on demand for life and health insurance. ${ }^{122}$ The empirical results are mixed, ${ }^{123}$ however, with some studies finding positive ${ }^{124}$ results and others finding negative ones. ${ }^{125}$

\footnotetext{
${ }^{120}$ See Mobarak and Rosenzweig (2012).

${ }^{121}$ An assessable mutual is one in which the insurer is able to request additional contributions from the policyholders after conclusion of the policy contract period when full loss and cost information is available.

122 See Outreville (2013).

${ }^{123}$ For an extensive list of studies, see Zietz (2003).

${ }^{124}$ See Browne and Kim (1993); Bernheim (1991).

${ }^{125}$ See Rejda et al. (1987); Lewis (1989).
} 
The crowding out issue between formal and informal insurance mechanisms is an important one for microinsurance market development. To the extent that well-functioning informal systems exist, caution is warranted in introducing insurance schemes that could be perceived as substitutes. Furthermore, developing a deeper understanding of the factors that foster success and prevent failure of informal systems will make future microinsurance efforts more sustainable. Landmann et al., ${ }^{126}$ for instance, observe that formal insurance crowds out solidarity. When secret saving ${ }^{127}$ is possible, however, crowding out is less likely because solidarity levels are already low. Greater understanding of the context, therefore, is key for microinsurance success, both as a business and as a way of providing social value.

\subsubsection{Quality of service}

Evidence for microinsurance: De Allegri et al. ${ }^{128}$ suggest that the decision to enrol in community-based health insurance in rural West Africa is closely linked to the quality of the health centre. In Uganda, Basaza et al. ${ }^{129}$ find that poor-quality health care is an important reason for people not to join. Dong et al. ${ }^{130}$ note that along with health needs and health demands, quality of care is an important factor in insurance drop-out. Jehu-Appiah et al. ${ }^{131}$ find that health care provider attitudes are important for households in deciding to enrol in the national health insurance scheme in Ghana. Similarly, Nguyen and Knowles ${ }^{132}$ find that demand for health insurance in Vietnam increases significantly with the expected benefits of insurance as measured by distance to and quality of a provincial hospital.

\footnotetext{
${ }^{126}$ See Landmann et al. (2012).

${ }^{127}$ In some communities, saving secretly (i.e., without other members of the community observing) may not be possible due to the closeness of the community members.

${ }^{128}$ See De Allegri et al. (2006).

${ }^{129}$ See Basaza et al. (2008).

${ }^{130}$ See Dong et al. (2009).

${ }^{131}$ See Jehu-Appiah et al. (2011).

${ }^{132}$ See Nguyen and Knowles (2010).
} 
Comparison with evidence for traditional insurance: There is some evidence in the developed markets that quality of care is an important determinant of health insurance takeup. Costa and Garcia ${ }^{133}$ find that quality of services (e.g., long waiting lists) explains the low demand for public health care in Spain, which provides universal access to health care. The role of quality in insurance demand (and likely other issues as well, such as adverse selection and moral hazard) is an appropriate topic for future research.

\subsubsection{Risk exposure}

Evidence for microinsurance: Several studies have investigated how risk exposure, particularly the effects of past shocks, affects demand for microinsurance. In a study of Sri Lanka, Arun et al. ${ }^{134}$ find strong evidence for a positive relationship, with past shocks increasing the probability of using microinsurance; however, Cole et al. ${ }^{135}$ and Galarza and Carter ${ }^{136}$ find no such evidence.

Comparison with evidence for traditional insurance: In developed markets, evidence suggests that people are more likely to purchase insurance right after a loss, consistent with the notion of 'availability bias'. ${ }^{137}$ Measures of country exposure, such as GDP, land resources, etc. also demonstrate a positive relationship with insurance purchase at the national level. ${ }^{138}$ This area of research has great potential for expansion.

\footnotetext{
133 See Costa and Garcia (2003).

${ }^{134}$ See Arun et al. (2012).

135 See Cole et al. (2013).

${ }^{136}$ See Galarza and Carter (2010).

137 See Johnson et al. (1993); Kunreuther (1996); Kunreuther and Pauly (2005).

138 See Browne and Kim (1993) among others.
} 


\subsection{Personal and demographic factors}

\subsubsection{Age}

Evidence for microinsurance: Age has been included in many of the empirical studies of microinsurance demand, yet generally done so as a control, rather than as a variable of particular interest. In some settings, such as life and health insurance, age likely represents loss exposure. In other settings, however, the influence appears to generate from risk attitudes and utility functions. Cohen and Einav, for example, observe a U-shaped relationship between age and risk attitudes, as portrayed by choices of deductible levels. ${ }^{139}$ Halek and Eisenhauer observed similar results in insurance purchase decisions. ${ }^{140}$ In the microinsurance literature to date, the results with regard to age have been ambiguous. Some studies find that age has a positive effect on demand; ${ }^{141}$ others find a negative effect ${ }^{142}$ or none. ${ }^{143}$ For life insurance, Arun et al. ${ }^{144}$ find no evidence of a life-cycle effect as take-up decreases with age (and increases after a certain point), which is in contrast with Giesbert et al., ${ }^{145}$ who note that takeup increases with age.

Comparison with evidence for traditional insurance: For traditional insurance markets, the effect of age on demand is ambiguous, with studies finding a positive, ${ }^{146}$ negative, ${ }^{147}$ or no effect. ${ }^{148}$ These results, however, may reflect the U-shaped relationship as identified in the Cohen and Einav (2007) and Halek and Eisenhauer (2001). Similar tests seem warranted in the microinsurance market.

\footnotetext{
139 See Cohen and Einav (2007).

140 See Halek and Eisenhauser (2001).

141 See Cao and Zhang (2011); Chen et al. (2013).

142 See Giné et al. (2008).

143 See Cole et al. (2013).

144 See Arun et al. (2012).

145 See Giesbert et al. (2011).

${ }^{146}$ See Truett and Truett (1990).

${ }^{147}$ See Bernheim (1991); Chen et al. (2001).

${ }^{148}$ See Gandolfi and Miners (1996).
} 


\subsubsection{Gender}

Evidence for microinsurance: Risk attitudes of women have been perplexing to researchers for some time. The majority, although certainly not all, research on the topic appears to demonstrate lower risk tolerance by women than men, even though the cause is unclear either theoretically or empirically. ${ }^{149}$ Lower risk tolerance ought to translate into greater levels of insurance purchase. The evidence regarding gender and microinsurance takeup, however, is mixed. Studies show that households headed by women are more likely, ${ }^{150}$ as likely, ${ }^{151}$ or less likely ${ }^{152}$ to enrol in insurance than households headed by men.

Comparison with evidence for traditional insurance: Similar results are observed in the traditional insurance markets. For example, Cohen and Einav and Halek and Eisenhauer both find greater risk aversion among women. ${ }^{153}$ Gandolfi and Miners ${ }^{154}$, however, observe that differences in purchase decisions of men and women depend on women's labour force participation.

\section{Comparison of microinsurance and traditional insurance and future research}

Based on the above discussion of theoretical predictions and empirical findings regarding demand in both microinsurance and traditional insurance markets, we identify important areas for future research. In Table 5, we summarize what we know so far about the differences between traditional insurance and microinsurance markets. The structure of Table 5 follows that of Outreville ${ }^{155}$ and Zietz, ${ }^{156}$ who provide a comprehensive overview of

\footnotetext{
${ }^{149}$ See Borghans et al. (2009); Eckel and Grossman (2008); Cohen and Einav (2007). Eckel and Grossman (2008) note that field studies often conclude that women are more risk averse than men, whereas laboratory experiment findings are less conclusive.

${ }^{150}$ See Chankova et al. (2008); Nguyen and Knowles (2010).

${ }^{151}$ See Thornton et al. (2010).

152 See Bonan et al. (2012); De Allegri et al. (2006).

153 See Cohen and Einav (2007), and Halek and Eisenhauer (2001).

${ }^{154}$ See Gandolfi and Miners (1996).

155 See Outreville (2013).
} 
Table 5: Comparison of variables between traditional insurance and microinsurance

\begin{tabular}{|c|c|c|c|}
\hline \multirow[t]{2}{*}{ Factor } & \multicolumn{2}{|c|}{ Evidence regarding the effect on demand } & \multirow[t]{2}{*}{ Discussion } \\
\hline & $\begin{array}{l}\text { Traditional } \\
\text { insurance }^{157}\end{array}$ & Microinsurance & \\
\hline \multicolumn{4}{|l|}{ Economic factors } \\
\hline Income & Positive & Positive or no effect & $\begin{array}{l}\text { Income is more difficult to measure in } \\
\text { microinsurance markets, and may capture } \\
\text { correlation with wealth and other } \\
\text { household characteristics. }\end{array}$ \\
\hline Wealth & Positive & Positive & $\begin{array}{l}\text { Wealth may be a liquidity or credit } \\
\text { constraint measure in the microinsurance } \\
\text { market. While the effect is positive in both } \\
\text { markets, the underlying rationale may be } \\
\text { different and respond to distinct } \\
\text { conditions. }\end{array}$ \\
\hline $\begin{array}{l}\text { Income } \\
\text { inequality }\end{array}$ & Ambiguous & & No research for microinsurance. \\
\hline $\begin{array}{l}\text { Price of } \\
\text { insurance }\end{array}$ & Negative & Negative & $\begin{array}{l}\text { Even subsidized microinsurance has low } \\
\text { take-up rates. Search costs may play a } \\
\text { much larger role in microinsurance than in } \\
\text { traditional markets. }\end{array}$ \\
\hline Inflation rate & $\begin{array}{l}\text { Positive for property } \\
\text { insurance; negative } \\
\text { for life insurance }\end{array}$ & & No research for microinsurance. \\
\hline $\begin{array}{l}\text { Real interest } \\
\text { rate }\end{array}$ & Ambiguous & & No research for microinsurance. \\
\hline \multicolumn{4}{|c|}{ Personal and demographic factors } \\
\hline $\begin{array}{l}\text { Population } \\
\text { size/density }\end{array}$ & Positive & & No research for microinsurance. \\
\hline Urbanization & $\begin{array}{l}\text { Positive (some } \\
\text { exceptions) }\end{array}$ & & No research for microinsurance. \\
\hline Age & Ambiguous & Ambiguous & May depend on the type of insurance. \\
\hline Gender (female) & Positive & Ambiguous & $\begin{array}{l}\text { May depend on female labour market } \\
\text { participation. }\end{array}$ \\
\hline Risk exposure & Positive $^{158}$ & Ambiguous & $\begin{array}{l}\text { Under-researched area with high potential } \\
\text { for development. }\end{array}$ \\
\hline
\end{tabular}

\footnotetext{
156 See Zietz (2003).

${ }^{157}$ The signs are largely based on Outreville (2013) and Zietz (2003), except where noted.

${ }^{158}$ See Johnson et al. (1993); Kunreuther (1996).
} 
Table 5 [Continued]

\begin{tabular}{|c|c|c|c|}
\hline \multirow[t]{2}{*}{ Factor } & \multicolumn{2}{|c|}{ Evidence regarding the effect on demand } & \multirow[t]{2}{*}{ Discussion } \\
\hline & $\begin{array}{l}\text { Traditional } \\
\text { insurance }^{159}\end{array}$ & Microinsurance & \\
\hline \multicolumn{4}{|c|}{ Social and cultural factors } \\
\hline Risk aversion & Ambiguous & Mostly negative ${ }^{160}$ & $\begin{array}{l}\text { The negative effect in microinsurance may } \\
\text { well relate to trust and/or experience or } \\
\text { other factors. Understanding these factors } \\
\text { could provide insight into the traditional } \\
\text { market as well. }\end{array}$ \\
\hline $\begin{array}{l}\text { Trust and peer } \\
\text { effects }\end{array}$ & & Positive $^{161}$ & $\begin{array}{l}\text { Could trust also play a role in the } \\
\text { traditional market and be one cause for the } \\
\text { ambiguous effect of risk aversion? } \\
\text { Regarding peer effects, buying traditional } \\
\text { insurance is more likely a business-like } \\
\text { decision, with little influence (although not } \\
\text { zero) from peers. Testing the influence of } \\
\text { peers in both markets seems valuable, } \\
\text { especially to understand why the influence } \\
\text { exists. }\end{array}$ \\
\hline $\begin{array}{l}\text { Education/ } \\
\text { human capital }\end{array}$ & Ambiguous & Ambiguous & $\begin{array}{l}\text { The typical consumer of microinsurance } \\
\text { will have far less education than the typical } \\
\text { traditional insurance consumer. }\end{array}$ \\
\hline $\begin{array}{l}\text { Financial } \\
\text { literacy }\end{array}$ & & Mostly positive & $\begin{array}{l}\text { Financial literacy may be more relevant in } \\
\text { microinsurance because of far less } \\
\text { experience with the product than in } \\
\text { traditional markets. }\end{array}$ \\
\hline Religion & Negative for Muslim & Indefinite & $\begin{array}{l}\text { An interesting aspect to look at is fatalism, } \\
\text { a factor related to religion that may capture } \\
\text { attitudes toward risk in microinsurance } \\
\text { markets. }\end{array}$ \\
\hline \multicolumn{4}{|l|}{ Structural factors } \\
\hline $\begin{array}{l}\text { Financial } \\
\text { development or } \\
\text { banking sector } \\
\text { development }\end{array}$ & Positive & & $\begin{array}{l}\text { No specific research for microinsurance. } \\
\text { Results could reflect the strength of the } \\
\text { underlying infrastructure, which may } \\
\text { affect trust in outcomes. Related to 'quality } \\
\text { of service'. }\end{array}$ \\
\hline $\begin{array}{l}\text { Monopolistic } \\
\text { market }\end{array}$ & Negative & & No research for microinsurance. \\
\hline $\begin{array}{l}\text { Presence of } \\
\text { foreign } \\
\text { companies }\end{array}$ & Ambiguous & & $\begin{array}{l}\text { No research for microinsurance, although } \\
\text { may relate to the concepts of trust and peer } \\
\text { influence. }\end{array}$ \\
\hline $\begin{array}{l}\text { Market } \\
\text { concentration }\end{array}$ & Negative & & No research for microinsurance. \\
\hline
\end{tabular}

159 These are largely based on Outreville (2013) and Zietz (2003), except where noted.

${ }^{160}$ An exception is Ito and Kono (2010), but they test for prospect theory where risk-loving attitude explains low insurance demand.

${ }^{161}$ An exception to the positive effect of peers is Dercon et al. (2012), but they suggest that lack of trust in peers is responsible for the negative impact on demand. 
Table 5 [Continued]

\begin{tabular}{|c|c|c|c|}
\hline \multirow[t]{2}{*}{ Factor } & \multicolumn{2}{|c|}{ Evidence regarding the effect on demand } & \multirow[t]{2}{*}{ Discussion } \\
\hline & $\begin{array}{l}\text { Traditional } \\
\text { insurance }^{162}\end{array}$ & Microinsurance & \\
\hline $\begin{array}{l}\text { Legal } \\
\text { environment }\end{array}$ & Positive & & $\begin{array}{l}\text { Similar to financial development, the legal } \\
\text { environment may be a measure of } \\
\text { infrastructure. It also may be a reflection of } \\
\text { potential loss (property rights). }\end{array}$ \\
\hline $\begin{array}{l}\text { Enforcement of } \\
\text { property rights }\end{array}$ & Positive & & $\begin{array}{l}\text { May be a reflection of potential loss if } \\
\text { individual property rights are enforced. }\end{array}$ \\
\hline Social security & Ambiguous & & $\begin{array}{l}\text { May be associated with informal risk } \\
\text { sharing, a concept studied in the } \\
\text { microinsurance market. }\end{array}$ \\
\hline $\begin{array}{l}\text { Informal risk- } \\
\text { sharing }\end{array}$ & & Ambiguous & [See note above] \\
\hline $\begin{array}{l}\text { Quality of } \\
\text { service }\end{array}$ & & Positive & $\begin{array}{l}\text { Quality of service may be related to trust } \\
\text { as well as to the idea of financial sector } \\
\text { development. Services in microinsurance } \\
\text { markets are expected to be of lower quality } \\
\text { generally than those in markets with } \\
\text { traditional insurance. }\end{array}$ \\
\hline
\end{tabular}

As demonstrated in Table 5, numerous opportunities for future research are evident. Specifically, studying the influence of trust on insurance take-up, both in the traditional and microinsurance markets, appears warranted. Furthermore, the reasons for limited price and wealth effects appear connected to understanding and confidence in the insurance market. Cultural and demographic factors appear quite important in insurance demand. Finally, the ambiguous results for risk aversion need more research. Theory suggests that greater risk aversion ought to lead to higher microinsurance demand. Even empirically, the current inverse relationship may be due to seeing insurance as a risky product (trust and nonperformance). Once we control for insurance as a risky product, will we still see an inverse relationship? This is an important research question which must be answered empirically.

\footnotetext{
${ }^{162}$ These are largely based on Outreville (2013) and Zietz (2003), except where noted.
} 
Moreover, many variables that have been tested in the traditional insurance markets have yet to be analysed in microinsurance markets. Some of these variables may be relevant only when conducting tests across economies and/or time, such as inflation, interest rates, population density and urbanization, financial development, the legal environment, and enforcement of property rights. Yet these conditions appear to be quite influential within the microinsurance context. For instance, issues of trust have been identified as key factors in microinsurance demand, as noted above. Trust, in turn, is believed affected by the legal environment and enforcement of property rights. Greater appreciation for the influence of all of these factors can be expected to influence policymakers in their efforts to expand microinsurance markets. Cross-national and multi-period analyses, therefore, offer an important avenue for future research.

Based on the theoretical and empirical findings, we present, in Figure 1, a framework for future research. The 12 prominent variables (rectangles) discussed so far are observable variables, while the factors (ovals) that define these variables are latent, unobservable conditions. In addition to showing the anticipated effect of relevant variables, we also integrate interactions between these variables and how they influence demand. For example, we take contractual non-performance and basis risk to be a variable that affects the relationship between (1) risk aversion and microinsurance demand, as non-performance risk contributes to perceiving insurance as a risky activity, and (2) trust and microinsurance demand, as the higher the non-performance risk, the lower the level of trust in the insurer, shown as arrows connecting non-performance risk to risk aversion and to trust.

Furthermore, the empirical evidence suggests complex relationships among the factors themselves. For instance, economic factors (e.g., wealth) may affect social and cultural factors 
(e.g., risk aversion). Interventions and/or policies aimed at increasing microinsurance demand will need to take these substantive interactions into account. Figure 1 is built as a structural model, which is the basis of structural equation models used in empirical research. ${ }^{163}$ An empirical test of this model presents another opportunity for future research.

Figure 1: Structural model for microinsurance demand

Non-

performance and basis risk

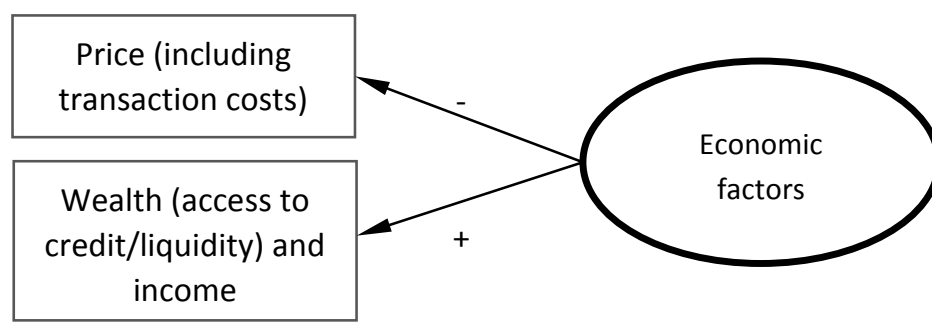




\section{Conclusion}

The last decade's expansion of academic research on microinsurance reveals some interesting patterns of what we know and, even more importantly, what we do not know about this increasingly important market. In this paper, we assembled the available research on microinsurance demand with the intent of identifying how the evidence compares and contrasts with evidence and theory for traditional insurance markets. The empirical evidence reveals several factors that are key in explaining the relatively low demand for microinsurance to date: price, wealth, risk aversion, non-performance risk, trust and peer effects, religion, financial literacy, informal risk sharing, quality of service, risk exposure, age, and gender. Importantly, most of these factors can be influenced by insurers, community leaders, aid agencies, and governments. Also important is recognition of the complex interaction between these factors and the need for far more research. Toward that goal, we present a framework for future research that can be tested empirically. 


\section{References}

Aizer, A. (2007) 'Public health insurance, program take-up, and child health', Review of Economics and Statistics 89(3): 400-415.

Akotey, O. J., Osei, K. A., and Gemegah, A. (2011) 'The demand for micro insurance in Ghana', Journal of Risk Finance 12(3): 182-194.

Akter, S., Brouwer, R., Chowdhury, S., and Aziz, S. (2008) 'Determinants of participation in a catastrophe insurance programme: Empirical evidence from a developing country’, paper presented at the 2008 (52nd) Australian Agricultural and Resource Economics Society Conference.

Arun, T., Bendig, M., and Arun, S. (2012) 'Bequest motives and determinants of micro life insurance in Sri Lanka’, World Development 40(8): 1700-1711.

Babbel, D. F. (1985) 'The price elasticity of demand for whole life insurance', Journal of Finance 40(1): 225-239.

Baicker, K., Congdon, W. J., and Mullainathan, S. (2012) 'Health insurance coverage and take-up: lessons from behavioral economics’, Milbank Quarterly 90(1): 107-134.

Bansak, C., and Raphael, S. (2006) 'The effects of state policy design features on take-up and crowd-out rates for the state children's health insurance program', Journal of Policy Analysis and Management 26(1): 149-175.

Bartke, S., and Schwarze, R. (2008) 'Risk-averse by nation or by religion? Some insights on the determinants of individual risk attitudes', SOE papers on multidisciplinary panel data research, DIW Berlin.

Basaza, R., Criel, B., and Van der Stuyft, P. (2008) 'Community health insurance in Uganda: Why does enrolment remain low? A view from beneath’, Health Policy 87(2): 172-184.

Bauchet, J. (2013) 'Price and information type in life microinsurance demand: Experimental evidence from Mexico’, job market paper, New York University, New York.

Beck, T., and Webb, I. (2003) 'Economic, demographic, and institutional determinants of life insurance consumption across countries', World Bank Economic Review 17(1): 51-88.

Bernheim, B. D. (1991) 'How strong are bequest motives? Evidence based on estimates of the demand for life insurance and annuities’, Journal of Political Economy 99(5): 899-927.

Biener, C., and Eling, M. (2012) 'Insurability in microinsurance markets: An analysis of problems and potential solutions’, Geneva Papers on Risk and Insurance 37(1): 77-107.

Binswanger, H. P. (1981) 'Attitudes toward risk: Theoretical implications of an experiment in rural India’, Economic Journal 91(364): 867-890.

Borghans, L., Golsteyn, B. H. H., Heckman, J. J., and Meijers, H. (2009) 'Gender differences in risk aversion and ambiguity aversion', Journal of the European Economic Association 7(2-3): 649-658. 
Bonan, J., Dagnelie, O., LeMay-Boucher, P., and Tenikue, M. (2012) 'Is it all about money? A randomized evaluation of the impact of insurance literacy and marketing treatments on the demand for health microinsurance in Senegal', ILO Microinsurance Innovation Facility Research Paper No. 14. Geneva: International Labour Organization.

Browne, M. J., and Kim, K. (1993) 'An international analysis of life insurance demand', Journal of Risk and Insurance 60(4): 616-634.

Cai, H., Chen, Y., Fang, H., and Zhou, L. (2009) 'Microinsurance, trust and economic development: evidence from a randomized natural field experiment', working paper 15396, National Bureau of Economic Research, Boston, MA.

Cai, J., Janvry, A. D., and Sadoulet, E. (2011) 'Social networks and insurance take up: evidence from a randomized experiment in China', ILO Microinsurance Innovation Facility Research Paper No. 8, Geneva: International Labour Organization.

Cai, J., and Song, C. (2011) 'Insurance take up in rural China: Learning from hypothetical experience', Mimeo.

Cao, Y., and Zhang, Y. (2011) 'Hog insurance adoption and suppliers' discrimination: A bivariate probit model with partial observability’, paper presented at the 2011 Annual Meeting Agricultural and Applied Economics Association, Pennsylvania.

Cappelletti, G., Guazzarotti, G., and Tommasino, P. (2012) 'What determines annuity demand at retirement?' Geneva Papers advance online publication 24 October 2012; doi: 10.1057/gpp.2012.43.

Cardenas, J., and Carpenter, J. C. (2008) 'Behavioural development economics: Lessons from field labs in the developing world’, Journal of Development Studies 44(3): 311-338.

Chankova, S., Sulzbach, S., and Diop, F. (2008) 'Impact of mutual health organizations: evidence from West Africa’, Health Policy and Planning 23(4): 264-276.

Chen, K., Hu, W., Xiao, C., and Xing, L. (2013) 'Smallholder participation in hog insurance and willingness to pay for improved policies: Evidence from Sichuan province in China', ILO Microinsurance Innovation Facility Research Paper No. 28, Geneva: International Labour Organization.

Chen, R., Wong, K. A., and Lee, H. C. (2001) 'Age, period, and cohort effects on life insurance purchases in the US’, Journal of Risk and Insurance 68(2): 303-327.

Clarke, D. (2011) 'A theory of rational demand for index insurance', discussion paper 572, University of Oxford, UK.

Clarke, D., and Kalani, G. (2012) 'Microinsurance decisions: Evidence from Ethiopia’, ILO Microinsurance Innovation Facility Research Paper No. 19, Geneva: International Labour Organization.

Cohen, A., and Einav, L. (2007) 'Estimating risk preferences from deductible choice', American Economic Review 97(3): 745-785. 
Cole, S., Giné, X., Tobacman, J., Topalova, P. B., Townsend, R. M., and Vickery, J. I. (2013) 'Barriers to household risk management: evidence from India', American Economic Journal: Applied Economics 5(1): 104-135.

Cole, S., Sampson, T., and Zia, B. (2011) 'Prices or knowledge? What drives demand for financial services in emerging markets?’ Journal of Finance 66(6): 1933-1967.

Costa, J., and Garcia, J. (2003) 'Demand for private health insurance: How important is the quality gap?’ Health Economics 12(7): 587-599.

De Allegri, M., Sanon, M., Bridges, J., and Sauerborn, R. (2006) 'Understanding consumers' preferences and decision to enrol in community-based health insurance in rural West Africa', Health Policy 76(1): 58-71.

De Bock, O., and Gelade, W. (2012) 'The demand for microinsurance: A literature review', ILO Microinsurance Innovation Facility Research Paper No. 26, Geneva: International Labour Organization.

Dercon, S., Gunning, J. W., and Zeitlin, A. (2011) 'The demand for insurance under limited credibility: Evidence from Kenya', paper presented at International Development Conference, DIAL, Paris.

Dercon, S., Gunning, J. W., Zeitlin, A., Cerrone, C., and Lombardin, S. (2012) 'Health insurance participation: Experimental evidence from Kenya', ILO Microinsurance Innovation Facility Research Paper No. 10, Geneva: International Labour Organization.

Doherty, N. A., and Schlesinger, H. (1990) 'Rational insurance purchasing: Consideration of contract nonperformance’, Quarterly Journal of Economics 105(1): 243-253.

Dong, H., De Allegri, M., Gnawali, D., Souares, A., and Sauerborn, R. (2009) 'Dropout analysis of community-based health insurance membership at Nouna, Burkina Faso', Health Policy 92(2-3): 174-179.

Eckel, C. C., and Grossman, P. J. (2008) 'Men, women, and risk aversion: Experimental evidence', in C. R. Plott and V. Smoth (eds.), Handbook of Experimental Economics Results, Volume 1, Amsterdam: North-Holland, pp. 1106-1118.

Eisenhauer, J. G., and Halek, M. (1999) 'Prudence, risk aversion, and the demand for life insurance’, Applied Economic Letters 6(4): 239-242.

Eling, M., and Marek, S. D. (2013) 'Corporate governance and risk taking: Evidence from the U.K. and German insurance markets', Journal of Risk and Finance advance online publication 10 April 2013; DOI: 10.1111/j.1539-6975.2012.01510.x.

Fafchamps, M., and Lund, S. (2003) 'Risk-sharing networks in rural Philippines', Journal of Development Economics 71(2): 261-287.

Feyen, E., Lester, R., and Rocha, R. (2011) 'What drives the development of the insurance sector’, Policy Research Working Paper No. 5572, World Bank, Washington, DC. 
Fitzpatrick, A., Magnoni, B., and Thornton, R. L. (2011) 'Microinsurance utilization in Nicaragua: A report on effects on children, retention, and health', ILO Microinsurance Innovation Facility Research Paper No. 5, Geneva: International Labour Organization.

Galarza, F. B., and Carter, M. R. (2010) 'Risk preferences and demand for insurance in Peru: A field experiment', paper presented at the 2010 Agricultural and Applied Economics Association Annual Meeting, Denver, CO.

Gandolfi, A. S., and Miners, L. (1996) 'Gender-based differences in life insurance ownership’, Journal of Risk and Insurance 63(4): 683-693.

Gaurav, S., Cole, S., and Tobacman, J. (2011) 'Marketing complex financial products in emerging markets: Evidence from rainfall insurance in India', Journal of Marketing Research 48(Special Issue): 150-162.

Gheyssens, J., and Gunther, I. (2012) 'Risk experiments in gains and losses: A case study for Benin’, working paper no. 2012/38, UNU-WIDER, Helsinki.

Giesbert, L., Steiner, S., and Bendig, M. (2011) 'Participation in micro life insurance and the use of other financial services in Ghana’, Journal of Risk and Insurance 78(1): 7-35.

Giné, X., Karlan, D., and Ngatia, M. (2011) 'Social networks, financial literacy and index insurance’, discussion paper, Yale Department of Economics, New Haven.

Giné X., Townsend, R., and Vickery, J. (2008) 'Patterns of rainfall insurance participation in rural India’, World Bank Economic Review 22(3): 539-566.

Gollier, C. (2003) 'To insure or not to insure? An insurance puzzle', Geneva Papers on Risk and Insurance Theory 28(1): 5-24.

Halek, M. and Eisenhauer, J.G. (2001) 'Demography of Risk Aversion,” Journal of Risk and Insurance 68(1): 1-24.

Hecht, C., and Hanewald, K. (2010) 'Sociodemographic, economic, and psychological drivers of the demand for life insurance: Evidence from the German retirement income act', SFB 649 Discussion Paper, Humboldt-Universität zu Berlin, Berlin.

Holt, C. A., and Laury, S. K. (2002) 'Risk aversion and incentive effects', American Economic Review 92(5): 1644-1655.

Ito, S., and Kono, H. (2010) 'Why is the take-up of microinsurance so low? Evidence from a health insurance scheme in India', Developing Economies 48(1): 74-101.

Jehu-Appiah, C., Aryeetey, G., Agyepong, I., Spaan, E., and Baltussen, R. (2011) 'Household perceptions and their implications for enrolment in the national health insurance scheme in Ghana', Health Policy and Planning online publication 18 April, doi: 10.1093/heapol/czr032

Johnson, E. J, Hershey, J., Meszaros, J., and Kunreuther, H. (1993) 'Framing, probability distortions, and insurance decisions’, Journal of Risk and Uncertainty 7(1): 35-51. 
Jowett, M. (2003) 'Do informal risk sharing networks crowd out public voluntary health insurance? Evidence from Vietnam’, Applied Economics 35(10): 1153-1161.

Jutting, J. P. (2003) 'Do community-based health insurance schemes improve poor people's access to health care? Evidence from rural Senegal', World Development 32(2): 273-288.

Kahneman, D., and Tversky, A. (1979) 'Prospect theory: An analysis of decisions under risk', Econometrica 47(2): 263-292.

Karlan, D., Osei-Akoto, I., Osei, R., and Udry, C. (2012) 'Agricultural decisions after relaxing credit and risk constraints', ILO Microinsurance Innovation Facility Research Paper No. 23, Geneva: International Labour Organization.

Kouame, E. B. H., and Komenan, A. (2012) 'Risk preferences and demand for insurance under price uncertainty: An experimental approach for cocoa farmers in Cote D'Ivoire', ILO Microinsurance Innovation Facility Research Paper No. 26, Geneva: International Labour Organization.

Kunreuther, H. (1996) 'Mitigating disaster losses through insurance', Journal of Risk and Uncertainty 12(3): 171-187.

Kunreuther, H., and Pauly, M. (2005) Insurance Decision Making and Market Behavior: Foundations and Trends in Microeconomics, Boston: Now Publishers.

Landmann, A., Vollan, B., and Frölich, M. (2012) 'Insurance versus savings for the poor: Why one should offer either both or none’, IZA Discussion Paper 6298, Bonn.

Latortue, A. (2006) 'The role of donors', in C. Churchill (ed.), Protecting the Poor: A Microinsurance Compendium Vol. I, Geneva: International Labour Organization, pp. 470 487.

Lewis, F. D. (1989) 'Dependents and the demand for life insurance', American Economic Review 79(3): 452-467.

Li, D., Moshirian, F., Nguyen, P., and Wee, T. (2007) 'The demand for life insurance in OECD countries', Journal of Risk and Insurance 74(3): 637-652.

Liu, Y., and Myers, R. J. (2012) 'The dynamics of insurance demand under liquidity constraints and insurer default risk', IFPRI Discussion Paper 01174, Washington, DC.

Lloyd's (2009) 'Insurance in developing countries: Exploring opportunities in microinsurance', $360^{\circ}$ Risk Insight Report, London.

Lusardi, A., and Mitchell, O. S. (2006) 'Financial literacy and planning: Implications for retirement well-being', DNB working paper 078, Netherlands Central Bank, Research Department.

Mantis, G., and Farmer, R. (1968) 'Demand for life insurance', Journal of Risk and Insurance 35(2): 247-256. 
Marquis, M. S., Buntin, M. B., Escarce, J. J., Kapur, K., and Yegian, J. M. (2004) 'Subsidies and the demand for individual health insurance in California', Health Services Research 39(5): 1547-1566.

Mobarak, A. M., and Rosenzweig, M. (2012) 'Selling formal insurance to the informally insured', discussion paper, Yale Department of Economics, New Haven.

Morduch, J. (1999) 'Between the state and the market: Can informal insurance patch the safety net?’ World Bank Research Observer 14(2): 187-207.

Morris, S. S., Carletto, C., Hoddinott, J., and Christiaensen, L. J. M. (2000) 'Validity of rapid estimates of household wealth and income for health surveys in rural Africa', Journal of Epidemiology and Community Health 54(5): 381-387.

Morsink, K., and Geurts, P. (2011) 'Informal trust building factors and the demand for microinsurance’, working paper, 7th Annual International Microinsurance Conference, Rio de Janeiro.

Mossin, J. (1968) 'Aspects of rational insurance purchasing', Journal of Political Economy 76(4): 553-568.

Nguyen, H., and Knowles, J. (2010) 'Demand for voluntary health insurance in developing countries: The case of Vietnam's school-age children and adolescent student health insurance program', Social Science and Medicine 71(12): 2074-2082.

Norton, M., Holthaus, E., Madajewicz, M., Osgood, D., Peterson, N., Gebremichael, M., Mullally, C., and Teh, T. L. (2011) 'Investigating demand for weather index insurance: Experimental evidence from Ethiopia', paper presented at the 2011 Annual Meeting Agricultural and Applied Economics Association, Pennsylvania.

Noussair, C., Trautmann, S., Kuilen, G. V. D., and Nathaneal, V. (2012) 'Risk aversion and religion', discussion paper, Tilburg University, Tilburg.

Outreville, J. F. (2013) 'The relationship between insurance and economic development: 85 empirical papers for a review of the literature', Risk Management and Insurance Review 16(1): 71-122.

Patt, A., Peterson, N., Carter, M., Velez, M., Hess, U., and Suarez, P. (2009) 'Making index insurance attractive to farmers', Mitigation and Adaptation Strategies for Global Change 14(8): 737-753.

Patt, A., Suarez, P., and Hess, U. (2010) 'How do smallholder farmers understand insurance, and how much do they want it? Evidence from Africa', Global Environmental Change 20(1): 153-161.

Rejda, G. E, Schmidt, J. R., and McNamara, M. (1987) 'The impact of social security tax contributions on group life insurance premiums', Journal of Risk and Insurance 54(4): $712-720$.

Sommer, D. W. (1996) 'The impact of firm risk on property-liability insurance prices', Journal of Risk and Insurance 63(3): 501-514. 
Sorensen, A. T. (2006) 'Social learning and health plan choice', RAND Journal of Economics 37(4): 929-945.

Tadesse, M., and Brans, M. V. (2012) 'Risk, coping mechanisms, and factors in the demand for micro-insurance in Ethiopia', Journal of Economics and International Finance 4(4): 79-91.

Thornton, R. L., Hatt, L. E., Field, E. M., Islam, M., Sol’ Diaz, F., and Gonzalez, M. A. (2010) 'Social security health insurance for the informal sector in Nicaragua: A randomized evaluation', Health Economics 19(S1): 181-206.

Truett, D. B., and Truett, L. J. (1990) 'The demand for life insurance in Mexico and the United States: A comparative study', Journal of Risk and Insurance 57(2): 321-328.

Wakker, P., Thaler, R., and Tversky, A. (1997) 'Probabilistic insurance', Journal of Risk and Uncertainty 15(1): 7-28.

Xu, L., and Zia, B. (2012) 'Financial literacy around the world: An overview of the evidence with practical suggestions for the way forward', policy research working paper No. 6107, World Bank, Washington, DC.

Zhang, L., Wang, H., Wang, L., and Hsiao, W. (2006) 'Social capital and farmer’s willingness-to-join a newly established community-based health insurance in rural China', Health Policy 76(2): 233-242.

Zietz, E. N. (2003) 'An examination of the demand for life insurance', Risk Management and Insurance Review 6(2): 159-191. 